\title{
シュウ酸法による二酸化マンガンの有効酸素の分析に
} おいて金属イオンを添加する改良法についで

\section{The Improved Method Adding the Metal Ion in the Solution, to Determine the Available Oxygen in Manganese Dioxide by Oxalate}

佐々未熊三**, 伊藤 要**
Kumazo SASAKI, Kaname ITO

\section{1. 緒言}

マンガン鉱石中の二酸化マンガンの有效酸柋の你析法: 上しては,硫酸第一鉄法,シュウ酸拈よざシュウ酸りーダ 法(1),(2)，互酸法(1)，リン酸マンガン法(3), 過酸化水素 法(4)などが专るが，日本工業規格(2) ではシ二酸り一 ダ法が採用されている現状である。このう法は箱健たた め乾電池工業界などに和いて子実際に使用されているが 硫酸第一鉄洼に比較して一般飞 $\mathrm{MnO}_{2} \%$ の過大な分析

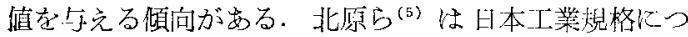
き，詳細㰸討して，試料の分解終了の確認が困難で文 ることを指摘し，末た，試料の分解彷上り生成する $\mathrm{Mn}^{2+}$ の接触作用でシュウ酸ソーダの一部が無為汇分解され， そのために過大な分析值を与亮ることを実験的征明し ている、また，一庎二酸化マンガンの有效酸素の竹析法

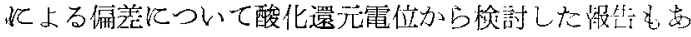

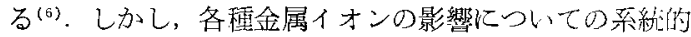
な研究は見当らない，それで著者らはシュ门酸の行解沉

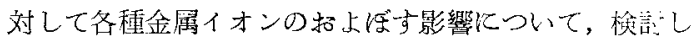

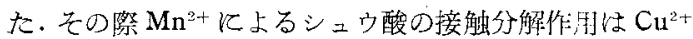
あるいは $\mathrm{Fe}^{3+}$ の添加炕よって抑制しうること琶好た。 この事実るシュウ酸による二酸化マンガンの分析泛汇適

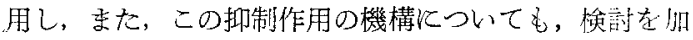
兑た.

\section{2. シュウ酸の分解におよぼす金属イオンの 影響について}

（1） $\mathbf{M n}^{2+}$ の影響について まずシュウ酸の分解 が $\mathrm{Mn}^{2+}$ の添加忙より促進される状態を知るために，そ の分解の時間的変化について検討した. 実験力法注 0.1 $\mathrm{N} \mathrm{H}_{2} \mathrm{C}_{2} \mathrm{O}_{4} 25 \mathrm{~m} l, 18 \mathrm{~N} \mathrm{H}_{2} \mathrm{SO}_{4} 5 \mathrm{~m} l=100 \mathrm{~m} l$ の三牦 フラスコにとり, さら飞 $\mathrm{Mn}^{2+} 2 \mathrm{~m} \mathrm{~mol}$ 在添加, 水孝扣

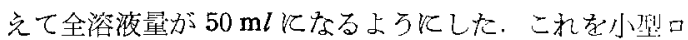
一トで覆い晹浴中で約 $90^{\circ} \mathrm{C}$ で一定時間加熱した後，0.1 $\mathrm{N} \mathrm{KMnO}_{4}$ 標潐溶液で滴定した。 な拓, $\mathrm{Mn}^{2+}$ 在港加乙

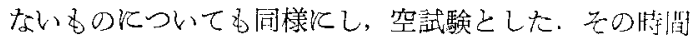
的変化を第 1 図沉示した.

* 昭和 33 年 4 月 27 日 電気化学協会学術請演会仁て一部㫰告

** 名古烝大学工学部空用化学教室（名古屋市干種区不老町）
$\mathrm{Mn}^{2+}$ 源加し 尔場合飞は， 6 $\mathrm{h}$ 加熱してもシュ ウ酸の分解情深之 んど起らなかった 交, $\mathrm{Mn}^{2+2} \mathrm{~m}$. mol 添加した場合 飞注 $4 \mathrm{~h}$ の加熱で $2.4 \%, 6 \mathrm{~h}$ では $6.5 \%$ の分解宗 Lt.

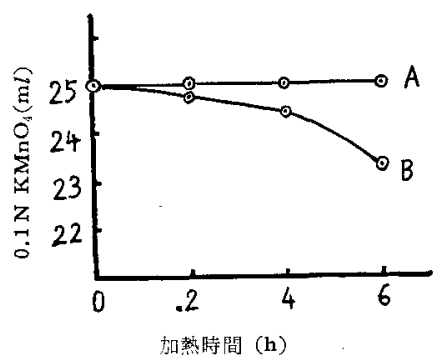

$$
\begin{aligned}
& \text { A : 空試験 } \\
& \text { B : } \mathrm{Mn}^{2}+2 \mathrm{~m} \text {. } \mathrm{mol} \text { 令有つ場合 } \\
& \text { 第 } 1 \text { 図 加熱時間 } の \text { 影䋨 }
\end{aligned}
$$

（2）他の金属イオンの影響について シュウ酸の 分解汇刘する金属イオン 1 種類の夕，扣よびこれらの金

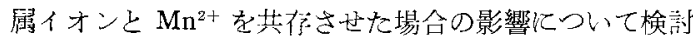

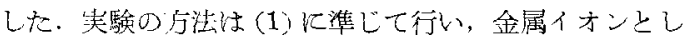
ては, $\mathrm{Cu}^{2+}, \mathrm{Fe}^{3+}, \mathrm{Ni}^{2+}, \mathrm{Co}^{2+}, \mathrm{Zn}^{2+}, \mathrm{Cd}^{2+}$ の硫酸㙁 $(0.5$ $\mathrm{mol} / l)$ 括よびバナジン酸アンモン溶没 $(0.01 \mathrm{~mol} / l)$ t 使朋した。 シュ酸 $1.25 \mathrm{~m} . \mathrm{mol}(0.1 \mathrm{~N}, 25 \mathrm{ml})$ 飞対乙 てこれらの金属イオン $0.5 \mathrm{~m} . \mathrm{mol}$ 添加した場合，拉上 び $\mathrm{Mn}^{2+} 2 \mathrm{~m} . \mathrm{mol}$ とこれらの金属イオン $0.5 \mathrm{~m}$.mol を 同時に添加した場合などについて実験した，第 1 表はこ れらの易苓について約 $90^{\circ} \mathrm{C}, 6 \mathrm{~h}$ 加熱したのちの $0.1 \mathrm{~N}$ $\mathrm{KMnO}_{4}$ 所用量宗しだのである。

\begin{tabular}{|c|c|c|c|c|}
\hline \multicolumn{2}{|c|}{ 添加された金属イオン } & \multicolumn{3}{|c|}{$0.1 \mathrm{~N} \mathrm{KMnO}_{4}$ 所用量 } \\
\hline $\mathrm{M}^{n+}$ & 㮇 斺 量 & $\mathbf{M}^{n+}$ & 万东添加 & $\begin{array}{c}\mathrm{Mn}^{2+}(2 \mathrm{~m} \text {.mol }) \\
+\mathrm{M}^{n+}\end{array}$ \\
\hline $\mathbf{M n}^{2+}$ & $2.0 \mathrm{~m} \cdot \mathrm{mol}$ & & $23.45 \mathrm{ml}$ & $-\mathrm{m} l$ \\
\hline $\mathrm{Mn}^{2+}$ & 0.5 & & 24.40 & - \\
\hline $\mathrm{Cu}^{2+}$ & 0.5 & & 24.95 & 24.82 \\
\hline$V^{5+}$ & 0.5 & & 24.91 & 24.20 \\
\hline $\mathrm{Fe}^{3+}$ & 0.5 & & 24.93 & 24.95 \\
\hline $\mathrm{Ni}^{2+}$ & 0.5 & & 24.98 & 24.19 \\
\hline $\mathrm{Co}^{2+}$ & 0.5 & & 24.91 & 22.95 \\
\hline $\mathrm{Zn}^{2+}$ & 0.5 & & - & 23.65 \\
\hline $\mathrm{Cd}^{2+}$ & 0.5 & & - & 23.24 \\
\hline \multicolumn{3}{|c|}{ 添加された $\mathbf{M}^{n+}(\mathrm{m} \cdot \mathrm{mol})$} & \multicolumn{2}{|c|}{$0.1 \mathrm{~N} \mathrm{KMnO}_{4}$ 所用量 } \\
\hline \multirow{3}{*}{\multicolumn{2}{|c|}{$\begin{array}{l}\mathrm{Fe}^{3}+(0.5)+\mathrm{Cu}^{2+}(0.5) \\
\mathrm{V}+(0.5)+\mathrm{Cu}^{2+}(0.5) \\
\mathrm{Cu}^{2+}+\mathrm{Fe}^{3+}+\mathrm{Co}^{2+}+\mathrm{Ni}^{2+}\end{array}$}} & & \multirow{3}{*}{\multicolumn{2}{|c|}{$\begin{array}{l}24.70 \mathrm{ml} \\
24.93 \\
24.87\end{array}$}} \\
\hline & & & & \\
\hline & & 各 0.5) & & \\
\hline
\end{tabular}

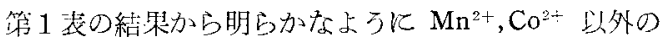
第 1 装 シュり酸の竹解飞及福す金属イオンの影響 
金属イオンはシュウ酸の分 解に奶学る影響の小さいこ とが楒わられる。また，過 酸化水素の分解の際に見ら れるよらな金属イオン間の 助触作用住なく，方。 $\tau \mathrm{Mn}^{2+}$ と $\mathrm{Cu}^{2+}$ 岁いは $\mathrm{Fe}^{3+}$ 虑共存させた場合に ほシェり酸の分解が特に減 少した。この点に着目して $\mathrm{Cu}^{2+}$ あるいは $\mathrm{Fe}^{3+}$ 添加の 影慜についてさらと詳䋖な

第 2 表 シュウ酸法（改是法）以よる二酸化マンガンの有效酸素の分析

\begin{tabular}{|c|c|c|c|c|c|c|}
\hline \multirow{2}{*}{ 㖑 } & \multirow{2}{*}{$\begin{array}{c}\text { 琉酸第一鉄 } \\
\text { 法作上各 } \\
\mathrm{MnO}_{2} \%\end{array}$} & \multirow{2}{*}{ 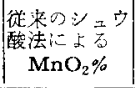 } & \multicolumn{4}{|c|}{ 设良ンェウ酸法による $\mathrm{MnO}_{2} \%$} \\
\hline & & & $\begin{array}{c}\mathrm{Cu}^{2+} \\
(0.5 \mathrm{~m} . \mathrm{mol})\end{array}$ & $\begin{array}{c}\mathrm{Cu}^{2+} \\
(0.1 \mathrm{~m} \cdot \mathrm{mol}) \\
\end{array}$ & $(0.5 \mathrm{Fe} \cdot \mathrm{mol})$ & $\begin{array}{c}\mathrm{Fe}^{3+} \\
(1.0 \mathrm{~m} \cdot \mathrm{mol})\end{array}$ \\
\hline $25 \mathrm{C}$ マンカン鉣 (N.B.S) & 90.53 & 90.94 & 90.57 & 90.64 & 90.60 & 90.58 \\
\hline 偏 差（\%) & & $(+0.46)$ & $(+0.04)$ & $(+0.12)$ & $(+0.08)$ & $(+0.06)$ \\
\hline ピカ産籍 & 85.47 & 85.79 & 85.48 & 85.48 & 85.49 & 85.39 \\
\hline 惼 美 (\%) & & $(+0.38)$ & $(+0.01)$ & $(+0.01)$ & $(+0.02)$ & $(-0.09)$ \\
\hline 川井產船 & 74.93 & 75.55 & 75.13 & 75.05 & 75.12 & 75.09 \\
\hline 偏 差 $(\%)$ & & $\{+0.83\}$ & $(+0.27)$ & $(+0.16)$ & $(+0.25)$ & $(+0.23)$ \\
\hline 電解二酸化マンガン & 85.31 & 87.17 & 85.33 & 85.19 & 85.33 & 85.38 \\
\hline 偏 差 (\%) & & $(+2.18)$ & $(+0.02)$ & $(-0.14)$ & $(+0.02)$ & $(+0.08)$ \\
\hline$\beta-\mathrm{MnO}_{2}\left[\mathrm{Mn}\left(\mathrm{NO}_{3}\right)_{2} よ り\right]$ & 94.20 & 95.44 & 94.40 & 94.24 & 94.24 & 94.09 \\
\hline 偳 美（\%) & & $(+1.32)$ & $(+0.21)$ & $(+0.04)$ & $(+0.04)$ & $(-0.12)$ \\
\hline
\end{tabular}

検討学行った。

\section{（3） $\mathbf{C u}^{2+}$ あるいは $\mathbf{F e}^{3 \div}$ の抑制作用について}

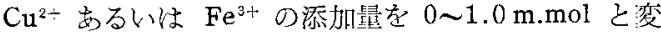
化し，他は（1）に準じた方法で実験した。約 $90^{\circ} \mathrm{C} て ゙ 6$ $\mathrm{h}$ 加蓺したのちの $0.1 \mathrm{~N} \mathrm{KMnO}_{4}$ 所用量恃符 2 図に不 军通りでめる。

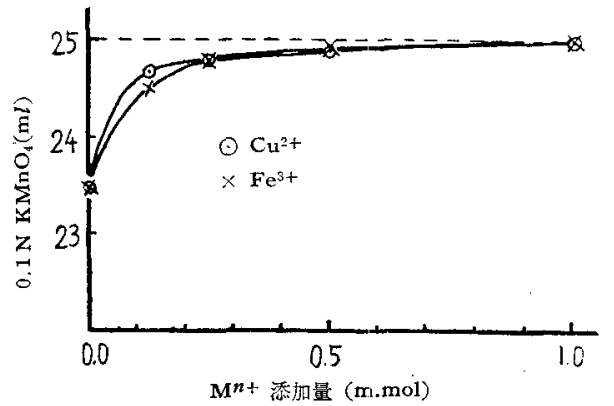

溶液: $0.1 \mathrm{~N} \mathrm{H}_{2} \mathrm{C}_{2} \mathrm{O}_{4} 25 \mathrm{ml}+18 \mathrm{~N} \mathrm{H}_{2} \mathrm{SO}_{4}$ $5 \mathrm{~m} l+\mathrm{Mn}^{2+} 2 \mathrm{~m} \cdot \mathrm{mol}+\mathrm{M}^{n+}+$ 水 $=50 \mathrm{~m} l$ 加熱：約 $90^{\circ} \mathrm{C}, 6 \mathrm{~h}$

第2図 $\mathrm{M}^{n+}\left(\mathrm{Cu}^{2+}, \mathrm{Fe}^{3+}\right)$ 影響

この $\mathrm{Mn}^{2+}$ の存在するシュウ酸溶腹 $\left(\mathrm{H}_{2} \mathrm{C}_{2} \mathrm{O}_{4} 1.25\right.$ $\mathrm{m} . \mathrm{mol}+\mathrm{Mn}^{2+} 2 \mathrm{~m} . \mathrm{mol}$ ) については 0.5 1.0 m.mol の $\mathrm{Cu}^{2+}$ 范るいは $\mathrm{Fe}^{3+}$ の添加炕よってシュ方酸の分解は 汪とんど起らなかった，したがって少量の $\mathrm{Cu}^{2+}$ 岁い は $\mathrm{Fe}^{3+}$ 老添加することによって， $\mathrm{Mn}^{2+}$ の接触作用に 基ら゙くシュウ酸の分解を抑制しうることが明らかルなっ た.この事实をシュウ酸による二酸化マンガンの分析法 に適用した。

\section{3. シュ ウ酸による二酸化マンガン分析法の} 改良

從来の分析法江招いて過大な分析值を与光る原因が反 応過程に颃いて生成与る $\mathrm{Mn}^{2+}$ のシュウ酸に効する接触 作用基ら゙くものとするならば，二酸化マンガンの試料 在分解寸る際 $\mathrm{Cu}^{2+}$ あるいは $\mathrm{Fe}^{3+}$ の少量をあらかじめ 添加して括けば，シュウ酸の無為な分解を防き正確な分 析值を与无る。と考光られる，よって，数種の二酸化
マンガン陚料について，この方法による你析を試み検訶 した。

二酸化マンガン試料には 100 メッシュ通過のものを $0.4 \mathrm{~g}$ 精ひょう（科）し，これに $0.2 \mathrm{~N} \mathrm{H}_{2} \mathrm{C}_{2} \mathrm{O}_{4} 50 \mathrm{~m} l$, $18 \mathrm{~N} \mathrm{H}_{2} \mathrm{SO}_{4} 12 \mathrm{~m} l$, さら飞 $\mathrm{Cu}^{2+}$ あるいは $\mathrm{Fe}^{2+}$ 0.5 $1.0 \mathrm{~m} . \mathrm{mol}$ 添加, 水党加光て $100 \mathrm{~m} l$ になるようにし これ安約 $90^{\circ} \mathrm{C}$ の晹浴中で $2 \mathrm{~h}$ 加熱分解したのち，0.1 $\mathrm{N} \mathrm{KMnO}_{4}$ 標华溶液で逆滴定した. 標集試料として $\mathrm{Na}$ tional Bureau of Standard (N.B.S.) 025 C, 二酸化 $\checkmark$

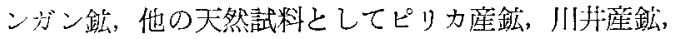
また，人造二酸化マンガンとして電解二酸化マンガン， 矿酸マンガンを加熱分解して造った $\beta-\mathrm{MnO}_{2}$ 学使用し た。この改良法を比較検討するためにこれらの暒料につ いて $\mathrm{Cu}^{\mathrm{i}+}$ 出るいは $\mathrm{Fe}^{3+}$ を添加しない嗞来法括よび硫 酸第一鉄法によって車分析し，をれらの結果をともに第 2 表に郝た。 この符 2 表の結果の内 N.B.S.の $25 \mathrm{C}$

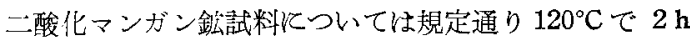
畭燥したものについての分析值で岁る。他の試料は風乾 試料についての分析值である。 また，第 2 表中力ッコ内 悓在最正正確な方法とされている硫酸第一鉄法に対す る偏差である。

従庆法で硫酸第一鉄法に比較して天然産マンガン鉱 で 0.38 〜 $0.83 \%$ 過大な值を得, 秀た人造二酸化マンガ ンについては 1.3〜2.2\% 過大な值を得た. それに反し て $\mathrm{Cu}^{2+}$ るいは $\mathrm{Fe}^{3+}$ を添加する改良法の分析值は土 0.27 名以下の徧差汇すざなかった。

前記の分析法で加熱時間を $2 \mathrm{~h}$ としたのは，1 h の加 熱で㤌少毁の黑色物が残ったが，1.5〜2hの加熱で黒色 物は消失したためである。ただし，ここで使用した電解 二:酸化マンガンは常に少量の黒色物が残り，これは長時 間加熱しても尔解やず，また過酸化水素の酸性溶液でる 分解しなかった：この試料は黒鉛電極を使用して造られ たすのである点などから黒色残留物恀電極から混入した 黒鈆であるると考光られる。

つぎ陚为の分解速度は $\mathrm{Cu}^{2+}$ あるいは $\mathrm{Fe}^{3+}$ の添加 によりほとんど影響をうけなかった，溶液の色は $\mathrm{Cu}^{2+}$ 
の添加で多少青色になり， $\mathrm{Fe}^{3 \leftarrow}$ の添加では黄色にな。 た.これらの焦は $\mathrm{KMnO}_{4}$ 溶液で滴定与る蔡, 終点近? でうすくなり終点の識別は無添加の場合に比して多少難 しいが，十分識别可能であった。

\section{4. $\mathbf{M n}^{2+}$ によるシュウ酸の接触分解におよぼ す諸因子の影響について}

$\mathrm{Cu}^{2+}$ 市よび $\mathrm{Fe}^{3+}$ の抑制作用の機構を明炕するために は，まず $\mathrm{Mn}^{2+}$ とよるシュウ酸の接触分解の機棈が明か。 にされなければならない，それでこの分解炕対する諸团 子の影響について検討した.

（1）酸素の影骦 $\mathrm{Mn}^{2+}$ の存在するシュり酸の硫 酸酸性溶腹に报いてい特別な酸化剂を添加しないにかか わらず加熱㭙シュウ酸が多少分解する, 一般にシュり酸 が分解するため瑺酸化剂が必要でする，この場命

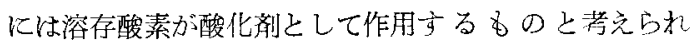
る、この点を明らか机するため，つぎの実験壱行った。

$100 \mathrm{ml}$ の三角フラスコに $\mathrm{Mn}^{2+}$ 学含しシュり酸溶液 $\left(0.1 \mathrm{~N} \mathrm{H}_{2} \mathrm{C}_{2} \mathrm{O}_{4} 25 \mathrm{~m} l, 18 \mathrm{~N} \mathrm{H}_{2} \mathrm{SO}_{4} 5 \mathrm{ml}, \mathrm{Mn}^{2+} 2 \mathrm{~m} . \mathrm{mol}\right.$ 括よび水を加况て $50 \mathrm{~m} l$ とした溶留）調製し，その 溶液酸菜ガス在通じつつ加熱できるごとくしたもの， $\mathrm{CO}_{2}$ むるいは $\mathrm{N}_{2}$ ガスを十分に通じブンゼンベンの栓孛 して酸䒺の影響を除去したもの，小型のロ一トの久で裂 ったをのを約 $90^{\circ} \mathrm{C}$ の湯浴中で $6 \mathrm{~h}$ 加熱した. 无の絈果 $0.1 \mathrm{~N} \mathrm{KMnO}_{4}$ の所用量第 3 表に示すごとくである.

第3表酸素の影響

\begin{tabular}{|c|c|c|c|}
\hline & 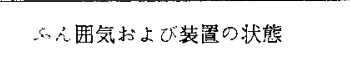 & $\left|\begin{array}{c}0.1 \mathrm{~N} \mathrm{KMnO}_{4} \\
\text { 所用量 }(\mathrm{m} l)\end{array}\right|$ & $\begin{array}{c}\mathrm{H}_{2} \mathrm{C}_{2} \mathrm{O}_{4} \\
\text { 分解率 }(\%)\end{array}$ \\
\hline (A) & 普通の状態 & 23.70 & 5.20 \\
\hline & 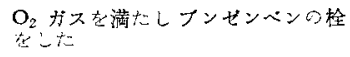 & 23.08 & 7.68 \\
\hline & $\mathrm{O}_{2}$ カ戊老吹入吼加熱 & 23.28 & 6.89 \\
\hline (C) & 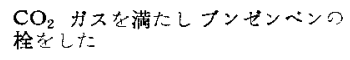 & 24.64 & 1.44 \\
\hline & $\mathrm{N}_{2}$ ガスを & 24.65 & 1.40 \\
\hline (D) & 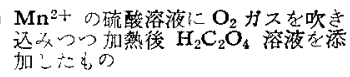 & 25.00 & 0.00 \\
\hline
\end{tabular}

$\mathrm{CO}_{2}$ ガス安るいは $\mathrm{N}_{2}$ ガスを通じてもシュウ酸の分解 を完全们防どことは出来なかったが，第 3 表からシュり 酸の分解については酸素に上る酸化が主反忍で㐫るこ上

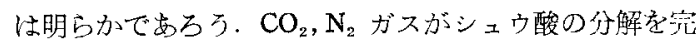
全に防ぎなかったのは溶存酸䒺の影響によるものと清 えられるがさらに奏験的検馀が必要である。

つぎに $\mathrm{Mn}^{2+}$ の夕を含导硫酸溶液 ( $18 \mathrm{~N} \mathrm{H}_{2} \mathrm{SO}_{4} 5 \mathrm{ml}$, $\mathrm{Mn}^{2+} 2 \mathrm{~m} . \mathrm{mol}$ 扎よ゙水を加党 $50 \mathrm{~m} l$ とした溶液) に $\mathrm{O}_{2}$ ガス吹込みの小 $6 \mathrm{~h}$ 加熱し, その後一定量の ュウ酸を加关て值ちに 0.1 N KMnO4標準溶液で滴定し た結果からはシュウ酸の分解を認め得なかった。したが って $\mathrm{Mn}^{2+}$ はこの硫酸酸性溶液中で $\mathrm{O}_{2}$ ガスによって酸
化されなかったものと考方られる。

(2) 光の影留 鉄, ウラニウムなどのシュウ酸塩 は光によってその分解が促進され，この事笑は青写真あ るいは光量計として実祭以使用されている(7). い未， $\mathrm{Mn}^{2+}$ の溶有するシュウ酸溶液について光の影響を検討 するため，つぎのごとき筷験を試みた。

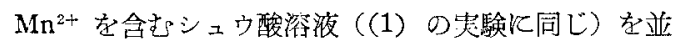
ガラス製 $100 \mathrm{~m} l$ 三角フラスコにとり，太陽直射，普通 の实験室内，䭫室で $6 \mathrm{~h}$ 加熱拓よび $24 \mathrm{~h}$ または $6 \mathrm{~h}$ 放 置して後, $\mathrm{KMnO}_{4}$ 標準溶液にて滴定した. 去の結果は 第 4 表に示す通りである.

$$
\text { 第 } 4 \text { 表 光 } の \text { 影響 }
$$

溶液: $0.1 \mathrm{~N} \mathrm{H}_{2} \mathrm{C}_{2} \mathrm{O}_{4} 25 \mathrm{~m} l+18 \mathrm{~N} \mathrm{H}_{2} \mathrm{SO}_{4} 5 \mathrm{~m} l+\mathrm{Mn}^{2+}+$ 水 $=50 \mathrm{~m} l$ 续用した容器: 普通のガラス製 $100 \mathrm{~m} l$ 三角フラスコを小型ロートで 覆つたる。

\begin{tabular}{|c|c|c|c|c|c|c|}
\hline 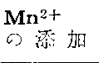 & 温度 & 䝰間 & & 态陽 & 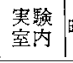 & 晴室内 \\
\hline $2 \mathrm{~m} \cdot \mathrm{mol}$ & $90^{\circ} \mathrm{C}$ & $6 \mathrm{~h}$ & $\begin{array}{l}0.1 \mathrm{~N} \mathrm{KMnO}_{4} \text { 所用量 } \\
(\mathrm{m} l) \\
\Sigma=\text { ウ酸分解率 }(\%)\end{array}$ & $\begin{array}{r}21.71 \\
13.3\end{array}$ & $\begin{array}{r}23.28 \\
6.9\end{array} \mid$ & $\begin{array}{c}23.30 \\
6.8\end{array}$ \\
\hline $2 \mathrm{~m} \cdot \mathrm{mol}$ & 常温 & 24 & 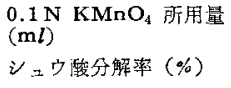 & $\left|\begin{array}{r}24.07 * \\
3.7\end{array}\right|$ & $\left|\begin{array}{c}24.90 \\
0.4\end{array}\right|$ & $\begin{array}{c}24.95 \\
0.2\end{array}$ \\
\hline 無添加 & $90^{\circ} \mathrm{C}$ & 6 & $\begin{array}{l}0.1 \mathrm{~N} \mathrm{KMnO}_{4} \text { 所用量 } \\
(\mathrm{m} l) \\
\nu_{\text {上丨酸分解率 }(\%)}\end{array}$ & $\begin{array}{c}24.90 \\
0.4\end{array}$ & $\left|\begin{array}{c}24.91 \\
0.4\end{array}\right|$ & $\begin{array}{c}25.00 \\
0.0\end{array}$ \\
\hline 無添加 & 常温 & 24 & $\begin{array}{l}0.1 \mathrm{~N} \mathrm{KMnO}_{4} \text { 所用量 } \\
(\mathrm{m} l) \\
V_{2} \text { ウ䣨分解率 }(\%)\end{array}$ & $\left|\begin{array}{r}25.00^{*} \\
0.0\end{array}\right|$ & $\left|\begin{array}{c}25.00 \\
0.0\end{array}\right|$ & $\begin{array}{c}25.00 \\
0.0\end{array}$ \\
\hline
\end{tabular}

* 二つ場合の放置時間は $6 \mathrm{~h}$

直射日光を热射した場含には明らかてその影響があら われるが普通の央験室と瞕室との差ははとんど認められ ない. $\mathrm{Mn}^{2+}$ の存在するシュウ酸溶液の分解は太陽光線 中の紫外線によって促進されるが, 実験室内での紫外線 は㾖とんどガラスに吸収されてその影響についてははと んど考慮定必要としない。

$\mathrm{H}_{2} \mathrm{C}_{2} \mathrm{O}_{4}-\mathrm{HgCl}_{2}-\mathrm{Mn}^{2+}$ 棌の水溶液方紫外線照射の誘 発反応によって水銀学定量する場合について桜場ら

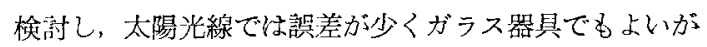
低厓水銀灯ては石英製容器を使用するか，ガラス製ビー カーならば上部より直接照射する必要があると迅べてい る. $\mathrm{H}_{2} \mathrm{C}_{2} \mathrm{O}_{4}-\mathrm{O}_{2}-\mathrm{Mn}^{2+}$ 系つ反応では上記塩化第二水銀の 代りに酸素を酸化剂とする場会である.したがって上記 奏験条件では，紫外線の影響を無視しうるすのと考光ら れる。

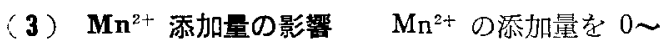
$8.0 \mathrm{~m} . \mathrm{mol}$ の䇚囲で変化し, シュウ酸の分解に括よぼす 影響について夷験した．他の条件は（1）の央験に準じ， 約 $90^{\circ} \mathrm{C}, 6 \mathrm{~h}$ 加熱乙た後の結果は第 3 図に示すごとくで ある.

シュウ酸の分解量々添加された $\mathrm{Mn}^{2+}$ の増加につれて 増大するがその増加率は減少する。 


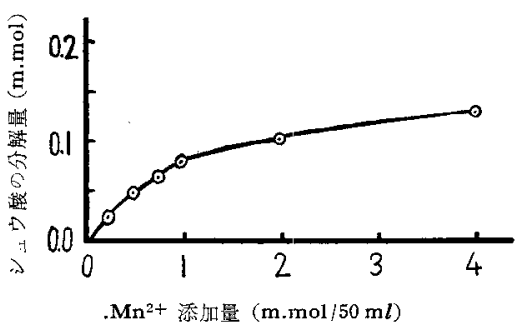

第3図 $\mathrm{Mn}^{2+}$ 添泇量の影響

（4）シュウ酸の濃度の影響つぎにシュウ酸の濃 度変化がその分解に括上ぼす影響について検㴻するため に，シニウ酸の採取量を $0.25 \sim 4.0 \mathrm{~m} . \mathrm{mol}$ の籁囲で変 北させ，他の条件は一定とし約 $90^{\circ} \mathrm{C}, 6 \mathrm{~h}$ 加热した。 そ 门絬果は第 4 図《示与通りでせる。

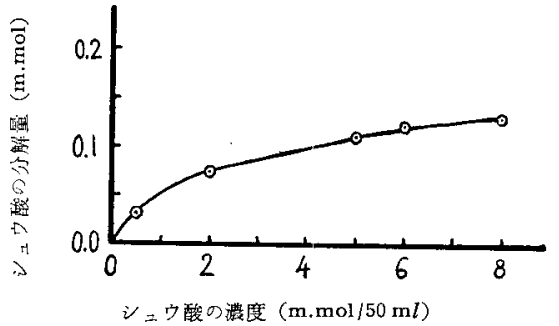

第 4 図シュウ酸门濃股の影響

第 4 図から加るようにシュウ酸の濃度の堌大に伴。 て，专の分解量は增加するが，必ずしも浱度に比例しな い。シュウ酸の濃度が小さくなる上その分解军は念激に 減少する。

な㧍，硫酸の濃度は $1 \sim 8 \mathrm{~N}$ の範囲ではシュウ酸の分 解军淂影しなかった。

\section{5. 考察}

(1) $\mathrm{Mn}^{2+}$ によるシュウ酸の接触分解について 酸素の影響江関する芙験結果 (第 3 表) から $\mathrm{Mn}^{2+}$ によ るシュウ酸の接触分解の主反応性酸素を酸化剂とすを。， $\mathrm{H}_{2} \mathrm{C}_{2} \mathrm{O}_{4}-\mathrm{O}_{2}-\mathrm{Mn}^{2+}$ 系の反応とるなしうる. $\mathrm{Mn}^{2+}$ のみの 硫酸酸性溶液化酸素を通じながら加熱した，第 3 表 (D)

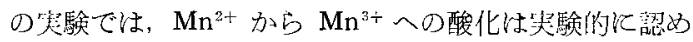
られなかった。また、シュウ醮の久の硫酸酸性溶液を加 熱した第 1 図Aに扔いてもシュ酸は汪とんど分解され なかった。しかるに $\mathrm{Mn}^{2+}$ 上シ口酸が共存する場合们 はシュウ酸の分解が認められ，その分解㧹は第 3,4 图か ら明らかなようにシュウ酸の淇度と $\mathrm{Mn}^{2+}$ の濃度飞依存 寸る.

この分解の機構については, $\mathrm{Mn}^{2+}$ の一部とシュ少酸 の一部から錯イオンがまず生成し，これに配位している シュウ酸が加熱などによって活性シュウ酸(8)上なり，こ れが溶存酸素上反灾して分解するか，さら飞 $\mathrm{Mn}^{2+}$ の酸 化反忍が進行して $\mathrm{Mn}^{3+}$ のシュウ酸鍇イオンとなり，直
ち酒位しているシュウ酸死酸化分解 ${ }^{(9),(10)}$ するものと 侾光られるがこれらの詳細な機構についてはさらに検討 する予定で岕る。

\section{（2） $\mathbf{C u}^{2+}$ あるいは $\mathbf{F e}^{3+}$ の抑制作用について} $\mathrm{Cu}^{2++}, \mathrm{Fe}^{3+}, \mathrm{Mn}^{2+}$ のシュウ酸錯塩の安定度飞ついては， Mellor $ら^{(11)}$ とより提案された二価金属イオンの錯塩安

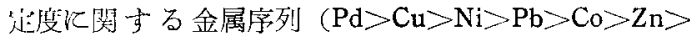
$\mathrm{Cd}>\mathrm{Fe}>\mathrm{Mn}>\mathrm{Mg})$ Kよれば $\mathrm{Cu}^{2+}$ は $\mathrm{Mn}^{2+}$ 上りかな り安定である。また，遷移金属林はをのイオン化

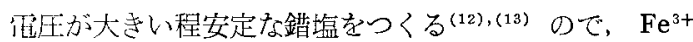
の錯盐快 $\mathrm{Fe}^{2+}$ のそれよりるかなり安定で，したがって $\mathrm{Mn}^{2+}$ の錯监上りも安定であるう。李た，Bjerrum ${ }^{(14)}$ に 占れば $\mathrm{Cu}^{2+}, \mathrm{Fe}^{3+}, \mathrm{Mn}^{2+}$ のシュウ酸との錯塭生成避離 エネルギーは $3.8,5.5,3.0 \mathrm{cal} / \mathrm{mol}$ の值となっている. すなわり， $\mathrm{Cu}^{2+}, \mathrm{Fe}^{3+}$ のシュウ酸錯塩の方が $\mathrm{Mn}^{2+}$ のそ れ比してかなり安定であると考完うる。末た一方第 1

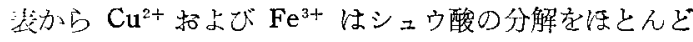
促谁しないことが認められる。

シュウ酸の酸素による分解が前述のごとく $\mathrm{Mn}^{2+}$ との 錯イオンの生成㶤上り促進されるすのとすれば, $\mathrm{Cu}^{2+}$ 古 るいは $\mathrm{Fe}^{3+}$ の排制作用については現在委での实験結果 から足性的炕つぎのごとく考光られる。すなわち，武料 二酸化マンガンとシュウ酸との硫酸酸性溶液を加熱する と二酸化マンガンは分解して $\mathrm{Mn}^{2+}$ 爻生成する。しかし 出らかでめ $\mathrm{Cu}^{2+}$ あるいは $\mathrm{Fe}^{3+}$ 索添加して括けば, $\mathrm{Cu}^{2+}$ 支るいは $\mathrm{Fe}^{3+}$ のシュウ酸錯 イオンの斿が生成し やすく, $\mathrm{Mn}^{2+}$ 汇配位するシュウ酸の量は少なく，した がって $\mathrm{Mn}^{2+}$ 亿去るシ二ウ酸の接蚛分解を扸制し，正 碓な分析值を与克るものと考光られるが，結論は今後の 研究の絬渠に河ずりたい。

\section{6. 総 括}

（1）金䣝イオンによるシュウ酸の接触分解について 枪矿 $\mathrm{L}, \mathrm{Mn}^{2+}$ とよるシュウ酸の接触分解梳かなり大き いが，少军の $\mathrm{Cu}^{2+}$ あるいは $\mathrm{Fe}^{3+}$ をさらに添加するこ

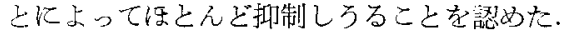

（2）この事実をシュウ酸による二酸化マンガンの分

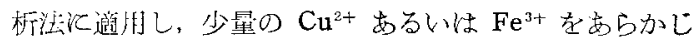

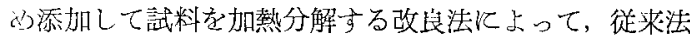

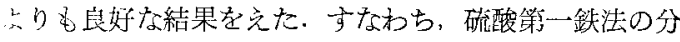

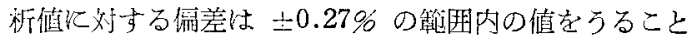
がで寻るようになった。

（3） $\mathrm{Mn}^{2+}$ Kよるシュウ酸の接触分解汇扮上ぼす諾 网子の影響について検討した。 その結果この分解は溶存 酸素安酸化剂乞乙 $\mathrm{Mn}^{2+}$ 学接触剤とする $\mathrm{H}_{2} \mathrm{C}_{2} \mathrm{O}_{4}-\mathrm{O}_{2}-$ $\mathrm{Mn}^{2+}$ 系の反応とみなしらる. 些験公内で法去の分解に 対して光の影響は压と儿ど認められないが，その分解量 は $\mathrm{Mn}^{2+}$ とシュウ酸の濃度飞低存する。 
（4）以上の奏験に基づきこの接触分解ね，まず溶液 中に $\mathrm{Mn}^{2+}$ のシュウ酸錯イオンが生成し，これが溶浡 酸素によって酸化分解されるものと考光られる. そして $\mathrm{Cu}^{2+}$ 特よび $\mathrm{Fe}^{3+}$ の抑制作用については，乙れらの金属

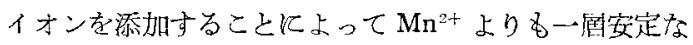
シュウ酸鍇塩を生成し， $\mathrm{Mn}^{2+}$ 亿配位するシュり酸の!寻 を減少させるのでシュウ酸の接触分解を抑制しろるるの としたがなな拓今後の研究を必棸とする。

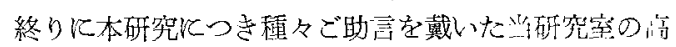
橋此彦助教授に感謝の意支表します。

(昭 34-3-27 受理)

文 献

（1）石橋雅載：基礎定量分析法，中巻 p. 286 (1949)
(2) J.I.S. M 8233 (1953)

(3) 谷野孝一: 科研報告, 32, 129 (1956)

(4) 佐々小熊三, 小沢昭弥：工北, 57, 193 (1954)

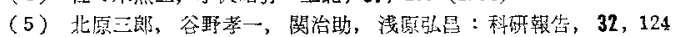
(1956)

（6）蟤木俊二，三宅義造：電化，学術講演会（第 25 回大会）因 33 年 4 月

(7) 奏駼化学講夾，6 卷, p. 283 (1956)

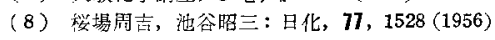

(9) H. Taube: J. Am. Chem. Soc., 70, 1216 (1948)

(10) F.R. Duke: J. Am. Chem. Sac., 69, 2885 (1947)

(11) D.P. Mellor, L. Maley: Nature, 159, 370 (1947)

(12) M. Calvin, N.C. Melchion: J. Am. Chem. Soc., 70, 3270 (1948)

(13) H. Irving, R.T.P. Williams : $\boldsymbol{f}$. Chem. Soc., 3192 (195.3)

(14) J. Bjerrum: Chem. Rev., 46, $381(1950)$

\title{
析出二酸化マンガンの性質および鉛合金陽極の挙動* \\ On the Properties of Deposited Manganese Dioxide and Behavior of Lead Alloy Anode
}

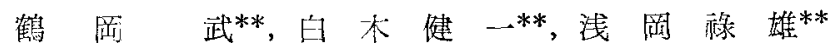 \\ Takeshi Tsuruoka, Kenichi SHrRoki, Rokuo Asaoka
}

\section{1. 緒 言}

電解二酸化マンガンの製造汇は陽極として不溶性䤼会 金と黒釦とが広く用いられている：これらの踢極炕よっ てつくられる二酸化マンガン柱として乾雷池の減極融 として用いられる.したがって，この二酸化マンガンは

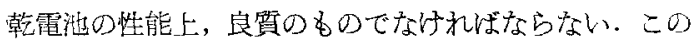

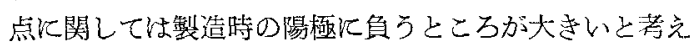

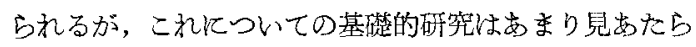
ないとそてて電解二酸化マンガン製造得最適した不溶 性陽極を得ることを目的として，不溶性陽極にしばしば 用いられる種々の鉛合金陽極で電解を行い，析出二酸化

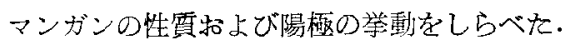

従来二酸化マンガン析出量招よび電流効率以温度の.上. 昇上ともに增加することが知られているが，この点を確 めながら，析出二酸化マンガンの有效酸素基ならびに陽

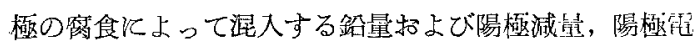
位などをも測定した，その結果，陽極電位と二酸化マシ

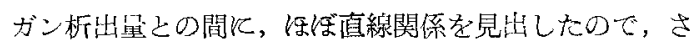
らにこの点を明らか机するために，陽極定篦位電解も行 った。これらの実験結果について述べる。

\section{2. 試料および実験方法}

\footnotetext{
* 二酸化マンカ゚ンの陽極析出に閔与る研究 Studies on the Electrodeposition of Manganese Dioxide 的利 33 年: 4 月

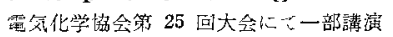

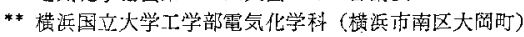

\section{i) 試 料}

陽極としてはつぎの六種類の㫟特よび鉛合金組成のる の爻用いた。

純鉛 $(99.99 \% \mathrm{~Pb})$, 鉛一銀 $(0.97 \% \mathrm{Ag})$, 䣄一ア ンチモン $(6.02 \% \mathrm{Sb})$, 鉛一七素 $(2.36 \% \mathrm{As})$, 踏一 カルシウム $(0.062 \% \mathrm{Ca})$, 鉛一テルル $(0.2 \% \mathrm{Te})$ 上記鉛合金の組成は不溶性陽極としてしばしば用いら れている点参考㣗して耐食坐の大きい共晶点附近の組

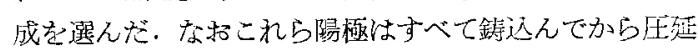
したものである。

陰極忙 18-8 ステンレス板とした。隍陽両極とも大き

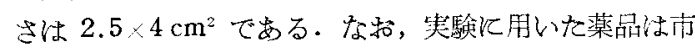
販の特級品である。

\section{ii) 実験方法}

装崱はガラ又製角型槽を電解槽上し，中央に陽極をは

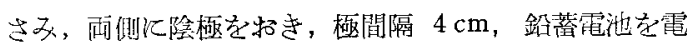

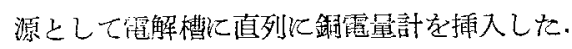

鼠解液怯 $200 \mathrm{cc}$ とし，その組成(1) $100 \mathrm{gMnSO}_{4} \div$ $33.5 \mathrm{~g}$ free $\mathrm{H}_{2} \mathrm{SO}_{4} / l$, 恒温槽で $30 \sim 80^{\circ} \mathrm{C}$ の䇺囲江开定 の温紊を保持させ，カキマゼは行わず，電流密度(1) 1 $\mathrm{A} / \mathrm{dm}^{2}(0.2 \mathrm{~A}$ 通電) で電解した。麗解時間はいずれる 5 h である。

電解を行う前飞鉛合金陽極はマンニットーアルカリー ヒドラジン(2)の熱溶液処理を行って，陽柾表面の酸化 被膜壱溶解除去してから用いた。

な招，上記定電流電解の他飞純鉛学陽極に用いて，上 